\title{
DIALOGUL INTERRELIGIOS CA IMPERATIV MISIONAR ÎN SOCIETATEA POSTMODERNĂ
}

Ioan Filimon*

\begin{abstract}
In the postmodern society, the globalization process is creating new and urgent problems for the entire mankind, being imperative that the various religios communities look together for effective answers. For facing these realities, there seems to be only one solution: the way of dialogue, in general, and of religious dialogue, in particular. The present paper aims at analysing interreligious dialogue, emphasizing its overwhelming importance in the given context. The first part presents the Christians' attitude to unchristian religions in the light of the Holy Scripture and the Holy Tradition; the second part explores aspects of interreligious dialogue from an Orthodox, Catholic and Protestant perspective; while the third part analyses the missionary imperatives of society nowadays. The paper ends with a few observations and conclusions.
\end{abstract}

Keywords: Ecumenism, Religions, Orthodox Mission, Christian Confessions, Conflict, Cooperation.

\section{Preliminarii}

Una din provocările cele mai importante ale societăţii postmoderne actuale este cea a dialogului ecumenic şi interreligios. Astăzi, peste tot în lume, schimbarea socio-politică contemporană creează o nouă situație în viaţa zilnică, în sensul că nu se poate vorbi despre un anumit teritoriu şi o religie unică, dar se poate cu uşurinţă găsi ceea ce s-ar putea numi un peisaj religios pluralist.

Problema colaborării interumane, a cooperării dintre religii,

* PhD Candidate at the Doctoral School of Theology of The University "1 Decembrie 1918" of Alba Iulia, Romania. 
atât la nivel local cât şi mondial, devine din ce în ce mai dificil de articulat, mai ales prin stările tensionate create după tragicul eveniment din Statele Unite ale Americii din 11 septembrie 2001, de experiența redefinirii unor granițe: cele mai apropiate exemple fiind războiul ruso-ucrainean, războiul dintre evrei şi palestinieni, criza din Orientul Mijlociu, tensiunile dintre musulmani şi creştini în Egipt, Siria şi Nigeria sau de gruparea teroristă ISIS, care acționează în diferite locuri de pe glob. „Toate aceste focare de luptă sunt alimentate din plin de ideologiile religioase, care depăşind sfera strictă a modalității de atingere a stării divine, au devenit ideologii ce hrănesc ambiții politice, fac propagande electorale sau justifică crime şi masacre cu caracter politico-religios" 1 . Aşadar, evenimentele tragice la care am asistat pasivi în ultimii ani, precum şi acelea la care suntem nevoiți să privim astăzi, demonstrează că absența dialogului dintre religiile lumii poate duce la o suferință şi mai mare, concretizată prin începerea unui nou război mondial. În fața acestor realități cu care se confruntă societatea postmodernă, soluția ar fi doar una: calea dialogului în general şi a celui religios, în special, indiferent că „mărturia prin dialog vine dinspre lumea creştină sau mozaică, dinspre Islam, India hindusă, spațiul budist, taoistoconfucianist, şintoist sau populațiile tribale contemporane"2. Astăzi, atât dialogul ecumenic cât şi cel interreligios sunt considerate imperative misionare, care au aceeaşi atitudine de deschidere către semeni şi de respect faţă de nişte culturi multă vreme considerate ostile, străine şi inferioare. Această deschidere nelimitată şi reciprocă pare a fi singura alternativă pentru a depăşi conflictele etnice şi religioase, sociale şi economice, terorismele şi fundamentalismele, care au măcinat umanitatea de la început şi care au fost izvor de suferinţă în toată istoria ei $^{3}$. Teologul Hans Küng subliniază: „Nu poate exista pace între națiuni fără pace între religii. Nu poate exista

Pr. conf. univ. dr. Emil Jurcan, Dialogul inter-religios în lumea contemporană, în „Orizonturi Teologice”, anul III, nr. 3, 2002, p. 84.

${ }^{2}$ Pr. Nicolae Achimescu, Religii în dialog, Iaşi, Editura Trinitas, 2006, p. 10.

${ }^{3}$ Pr. Gianfranco Maronese, Dialogul dintre oameni, în „Pax et Unitas”, nr. 3, 2004, p. 4. 
pace între religii fără un dialog între religii. Nu poate exista dialog între religii fără cercetarea fundamentelor teologice"4.

În acest context, reprezentanții marilor religii ar trebui să găsească mijloace şi să dezvolte strategii, metode şi instrumente care ajută la depăşirea stărilor conflictuale existente astăzi, care îşi au anumite cauze în domeniul religios ${ }^{5}$.

\section{Atitudinea față de religiile necreștine în lumina Sfintei Scripturi şi a Sfintei Tradiții}

Problema atitudinii şi a raportului creştinilor cu religiile lumii este stringentă pentru misiologia contemporană, ea constituind de altfel o problemă sensibilă pe tot parcursul istoriei creştine. Într-o lume care a devenit, sub aspect religios şi nu numai, o comunitate tot mai divizată, este firesc să se pună întrebarea care ar putea fi poziția creştinului autentic față de credincioşii altor religii într-o societate postmodernă? Pentru a da un răspuns la această provocare, se impune o scurtă incursiune biblică şi patristică în relația creștinilor cu oamenii altor credințe din perspectivă ortodoxă.

De multe ori s-a argumentat că noțiunea de „dialog” nu se găseşte în Biblie şi prin urmare dialogul ar fi lipsit de autoritatea biblică. Deşi

„substantivul «dialog» nu se găseşte în Biblie, totuşi relațiile prietenoase şi întâlnirile personale frecvente sugerate de verbul activ sunt evidenţiate în mod clar în paginile Sfintei Scripturi. Legătura lui Dumnezeu cu poporul Său ales şi cu celelalte neamuri, relațiile şi obligațiile reale implicate în legământul Său cu Noe şi cu Avraam, activitatea regilor şi judecătorilor, a profeților şi preoților, cartea lui Iov, scrierile profeților şi anumiți psalmi în care se prezintă întoarcerea poporului la Dumnezeu, toate acestea nu sugerează deloc un

${ }^{4}$ Hans Küng, Global Responsability: In Search of a New World Ethic, translation from German by John Bowden, SCM Press, 1991, p. 105.

${ }^{5}$ Editorial, Necesitatea dialogului interreligios, în „Teologia”, anul VII, nr. 1, 2003, p. 8. 
monolog",

De asemenea, în tot Noul Testament există forme de dialog. Astfel în el descoperim diferite momente în care Mântuitorul intră în legătură cu oamenii: dialogul cu Nicodim, cu femeia samarineancă, cu sutaşul şi cu propriii Săi ucenici în toată perioada activităţii Sale pământeşti. Există şi situații în care El refuză să intre în discuţii, prezența Sa divizând poporul, motiv pentru care nimeni nu poate exagera, pretinzând că pretutindeni în Sfânta Scriptură ar fi vorba doar de dialog ${ }^{7}$. Profesorii Terry Muck şi soția sa Frances Adeney susțin că în Biblie există 239 de locuri care se referă la întâlniri interreligioase, enumerându-le în ordine cronologică ${ }^{8}$.

Pentru a înţelege fundamentele religioase ale valorificării teologice ale celorlalte religii din punct de vedere ortodox, trebuie să analizăm punctele doctrinare specifice Bisericii Ortodoxe ce stau la baza dialogului. În tradiția ortodoxă problema dialogului cu alte religii se desfăşoară din punctul de vedere al învăţăturii despre Sfânta Treime?

Astfel, în Sfânta Scriptură se arată că există un singur Dumnezeu: „Căci Eu sunt Domnul Dumnezeu, şi nu este nici un Dumnezeu afară de Mine” (Is. 45, 3), acest Dumnezeu unic „Tată al tuturor, Care este peste toate şi prin toate şi întru toți” (Efes. 4, 6), Care a creat universul şi lucrează continuu în istorie. Existând un singur Dumnezeu, în Sfânta Scriptură se evidențiază originea

${ }^{6}$ Stanley J. Samartha, Dialogue as a Continuing Christian Concern, în „The Ecumenical Review", vol. 23, nr. 2, 1971, p. 139.

${ }^{7}$ Ibidem

8 Terry Muck şi Frances S. Adeney, Christianity Encountering World Religions: The Practice of Mission in the Twenty-first Century, Grand Rapids, Baker Academic, 2009, p. 379.

9 †Anastasios Yannoulatos, Ortodoxia şi problemele lumii contemporane, traducere de drd. Gabriel Mândrilă, pr. prof. dr. Constantin Coman, Bucureşti, Editura Bizantină, 2003, p. 168. A se vedea şi Adrian Boldişor, Poziția ortodoxă față de dialogul inter-religios. Dialogul cu islamul, în „Revista Teologică", Serie Nouă, anul XX (92), nr. 2, 2010, Sibiu, Editura Andreiana, pp. 211-212. 
comună a întregii umanități: „după chipul şi asemănarea lui Dumnezeu" (Fac. 1, 26-27) ${ }^{10}$. Căderea în păcat nu a distrus chipul lui Dumnezeu în om, acesta a avut de suferit fără a se distruge complet capacitatea lui de a primi şi înţelege mesajul lui Dumnezeu adresat lui. Toți oamenii au o legătură între ei prin demnitatea lor intangibilă şi originea divină, care niciodată nu se pierd. În decursul istoriei umanității, Dumnezeu nu a încetat să poarte de grijă de lumea pe care a creat-o, din contră, a ajutat-o şi a călăuzit-o. Din paginile Sfintei Scripturi aflăm că Dumnezeu a încheiat mai multe legăminte cu umanitatea: cu Adam şi Eva, cu Noe şi cu noua umanitate salvată de la potop (Fac. 8; 9, 12), cu Avraam (Fac. 12) etc., care continuă să-şi păstreze importanţa şi valabilitatea lor. Ultimul şi definitivul şi veşnicul „,nou legământ” s-a împlinit prin Iisus Hristos, noul Adam. Însă toți oamenii se află în relaţie cu Dumnezeu prin intermediul unui mai vechi legământ, pe care El Însuşi 1-a pecetluit. Pe de altă parte, avem exemple de oameni din Vechiul Testament are au respectat poruncile divine, cunoscându-L şi fiind în relaţie cu Dumnezeu, deşi nu erau israeliţi: Enoh, Melchisedec şi Iov. Întreaga Sfântă Scriptură arată universalitatea lui Dumnezeu: „Al Domnului este pământul şi plinirea lui; lumea şi toți cei ce locuiesc în ea” (Ps. 23, 1), „,..că Împărat peste tot pământul este Dumnezeu” (Ps. 49, 8), şi ,împărăția Lui stăpâneşte peste toți” (Ps. 102, 9). Profeții au vestit de asemenea cu claritate planul lui Dumnezeu de a aduna în ziua cea de pe urmă întreaga umanitate, ,aceasta e voia pe care a voit-o Domnul peste toată lumea, şi aceasta este mâna întinsă peste toate popoarele şi toate neamurile lumii (Is. 14, 26) sau „Căci de la răsăritul soarelui şi până la apusul lui ... numele Meu este slăvit printre neamuri, şi în orice parte se aduce tămâie pentru numele Meu şi jertfă curată, căci mare este numele Meu între neamuri, zice Domnul cel Atotputernic" $\left(\right.$ Mal. 1, 11) ${ }^{11}$.

Analiza teologică a celorlalte religii trebuie să se efectueze din perspectiva principiului creştin esenţial, cel al Intrupării Logosului în

${ }^{10}$ Ibidem, pp. 168-169.

${ }^{11}$ Ibidem, pp. 171-172. 
numele tuturor oamenilor din toate timpurile şi din toate locurile: „Dumnezeu atât de mult a iubit lumea, încât pe Fiul Său Cel UnulNăscut L-a dat ca oricine crede în El să nu piară, ci să aibă viață veşnică” (In. 3, 16) sau „Şi Cuvântul S-a făcut trup şi s-a sălăşluit între noi" (In. 1, 14), aceste versete ale Evangheliei după Ioan determinând temelia esențială hristologică a celor mai înalte inspirații religioase ale umanității. Prin faptele şi jertfa Sa, Hristos a dezlegat „faptele diavolului” (I Ioan 3, 8), elementul demonic contaminând toate religiile ${ }^{12}$.

Pe de altă parte, Însuşi Domnul Hristos arăta foarte multă dragoste şi smerenie pentru cei din afara comunităţii creştine. Hristos $\mathrm{n}$-a exclus din atenția Sa persoane de alte credințe. În anumite situații, în timpul vieții Sale pământeşti, El a stat de vorbă cu oameni de diferite tradiții religioase precum femeia samarineancă (In. 4, 142), femeia canaaneancă (Mt. 15, 21-28 şi Mc. 7, 24-30) şi sutaşul roman (Mt. 8, 10 cf. Lc. 7, 5), pe care i-a ajutat. El şi-a exprimat admirația şi respectul față de credința lor, pe care n-a găsit-o nici în Israel: ,....nici în Israel n-am găsit atâta credință" (Mt. 8, 10; Lc, 7, 9). Domnul Hristos a remarcat recunoştința celui vindecat de lepră, care era samarinean, iar în discuția cu femeia samarineancă i-a descoperit acesteia adevărul că Dumnezeu este Duh (In. 4, 4-30), folosind într-o pildă chiar imaginea bunului samarinean ca pe un exemplu de urmat al principiului fundamental al învățăturii Sale despre noua dimensiune a iubirii pe care El a predicat-o. „El, «Fiul Omului» care la Judecata de Apoi, se va identifica pe Sine cu «cei puțini» ai acestei lumi (Mt. 25) indiferent de rasă sau religie, ne îndeamnă să abordăm fiecare persoană umană cu dragoste şi respect autentic" "13. De asemenea în Faptele Apostolilor, ni se relatează despre credința sutaşului Corneliu (F. Ap. 10, 1-36), de unde învăţăm că ,în orice

\footnotetext{
12 Ibidem, pp. 173-174.

${ }^{13}$ Idem, Atitudinea Ortodoxiei față de alte religii, în „Cum să trăim Ortodoxia astăzi”, traducere din limba engleză de Doina Rogoti, Bucureşti, Editura Sophia, 2010, pp. 233-234. A se vedea şi ediţia în limba engleză Anastasios Yannoulatos, Orthodox Relations with Other Religions, în „Sourozh”, nr. 85, 2001, p. 13.
} 
neam, cel ce se teme de El şi face dreptate este primit de El” (F. Ap. 10, 35). Apoi Sfântul Pavel afirmă că ,în veacurile trecute Dumnezeu a lăsat toate neamurile să meargă pe căile lor. Deşi El nu s-a lăsat pe Sine nemărturisit, făcându-vă bine...” (F. Ap. 14, 16-17), arătând că tradiția primară şi mai ales apologetică a Bisericii primare a remarcat posibilitatea cunoaşterii naturale, şi deci parţiale a adevărului revelat în afara tradiției creştine revelate ${ }^{14}$.

Biserica, de la început, prin Sfinţii Apostoli şi urmaşii acestora, s-a angajat în proclamarea Evangheliei la necreştini şi încorporarea prin har şi credință a celor ce primeau învăţătura creştină şi harul Sfintelor Taine. Sensul evanghelizării era convertirea la Hristos printr-o argumentare religioasă. Un moment important în propovăduirea creştină către cei de altă credinţă este reprezentat de predica Sfântului Apostol Pavel în Areopag (F. Ap. 17, 22-31). În predica sa, după ce s-a referit la un fundament religios comun, trece la esența şi nucleul Evangheliei: importanța personalității şi a lucrării lui Hristos ${ }^{15}$.

Un alt punct semnificativ pentru dialogul interreligios din perspectivă ortodoxă este învățătura despre Duhul Sfânt: „pretutindeni fiind şi pe toate plinindu-le” (Rug. Impărate Ceresc). Duhul Sfânt continuă să lucreze pentru mântuirea fiecărei persoane şi a întregii lumi ca „,Duh al sfințeniei, al puterii, al adevărului, al păcii şi al dreptăţii” (Gal. 5, 22), mare parte din aceste elemente fiind prezente în viața multor oameni care aparțin diferitelor religii. Noi înaintăm în fiecare efort, chiar şi în dialogul interreligios, cerând călăuzirea şi luminarea Duhului Sfânt ${ }^{16}$.

În ceea ce priveşte Sfânta Tradiție, există multe exemple ale felului în care creştinii au privit şi s-au raportat la alte religii. În cele ce urmează ne vom referi selectiv doar la câteva poziții ale unor gânditori creştini, aparţinând unor epoci diferite, ştiind foarte bine că

\footnotetext{
14 Remus Rus, Concepția despre om în marile religii, teză de doctorat, Bucureşti, 1978, p. 191.

${ }^{15} \uparrow$ Anastasie Yannoulatos, Misiune pe urmele lui Hristos. Studii teologice şi omilii, traducere de Ştefan L. Toma, Sibiu, Editura Andreiana, 2013, p. 228.

${ }^{16}$ Idem, Ortodoxia şi problemele lumii contemporane, pp. 179-180.
} 
punctul lor de vedere exprimă şi opiniile altor Sfinți Părinți din aceeaşi perioadă. Raportându-ne la opiniile Sfinților Părinţi putem identifica cele trei modele actuale de evaluare a altor religii specifice teologiei moderne a religiilor: exclusivismul, inclusivismul şi pluralismul ${ }^{17}$.

Prin exclusivismul religios se afirmă că necreştinii vor fi pierduți, deoarece nu există mântuire în afara Trupului văzut al lui Hristos care este Biserica. Acest concept este asociat Sfântului Ciprian al Cartaginei datorită celebrei lui afirmații: „extra ecclesiam nulla salus", care a ajuns să fie folosită prin extensie pentru orice formă de exclusivim creştin, inclusiv pentru cel interreligios ${ }^{18}$.

Prin al doilea termen adică cel de inclusivism, se afirmă că necreştinii pot fi mântuiţi în ciuda religiilor pe care le practică, dar numai prin mila lui Dumnezeu. Cel care promovează această viziune este Sfântul Iustin Martirul şi Filosoful. În contextul lucrării creatoare universale a cuvântului Iustin a recurs la un concept stoic „logos spermatikos", susținând că fiecare parte a lumii are încorporată o sămânță a Logosului, prin Logos înțelegându-se Fiul Tatălui ${ }^{19}$. Pentru Iustin orice om poate participa la Cuvânt:

„Fiecare dintre aceştia, atunci când a văzut, în parte, apropierea lui de Cuvântul dumnezeiesc împrăştiat în lume, a putut să grăiască câte un adevăr parțial; dar cei care au vorbit lucruri contrare unii altora, în chestiunile cele mai însemnate, se pare că nu au avut nicio ştiință vădită şi nicio cunoştință neîndoioasă despre Cuvântul" ${ }^{\text {20 }}$.

Tipologiile sistematice exclusivism - inclusivism - pluralism apar pentru prima dată în cartea lui Alan Race, Christians and Religious Pluralism. Patterns in the Christian Theology of Religions, London, SCM Press, 1983.

${ }^{18}$ Pr. prof. univ. dr. Dorin Oancea, Teologia Religiilor în Biserica Primară: Athenagoras, Sf. Justin Martirul, Origen, în Nicolae Moşoiu (coord.), „Relevanța operei Părintelui Profesor Ion Bria pentru viaţa bisericească şi socială actuală. Direcții noi de cercetare în domeniul doctrinei, misiunii şi unității Bisericii”, Sibiu, Editura Universității „Lucian Blaga”, 2010, p. 270.

${ }^{19}$ Ibidem, p. 274.

${ }^{20}$ Sf. Iustin Martirul şi Filosoful, Apologeți de limbă greacă, PSB 2, Bucureşti, EIBMBOR, 1980, p. 87. 
Această teorie a „logosului seminal” a devenit principala metodă de apropiere folosită de Părinții Apostolici în încercarea lor de a formula un punct de vedere teologic privind relația dintre credința creştină şi religiile necreştine ${ }^{21}$.

A treia metodă prin care creştinii văd relația lor cu religiile necreştine este cea a pluralismului. Prin prisma acestui concept necreştinii pot fi mântuiți prin intermediul aceleiaşi religii pe care o practică, căci religiile necreştine pot de asemenea să conțină adevăruri mântuitoare. În lucrarea sa „Împotriva lui Celsus”, Origen afirmă că şi păgânilor le este accesibilă cunoaşterea lui Dumnezeu ${ }^{22}$.

Din punct de vedere teologic atitudinea Bisericii Ortodoxe față de alte religii pe întreg parcursul existenței sale a fost una pozitivă fără diluarea rolului lui Hristos în iconomia mântuirii, mai mult această atitudine fiind folosită ca o punte şi ca mijloc de a aduce împreună creştinii şi necreştinii.

\section{Aspecte ale dialogului interreligios din perspectivă ortodoxă, catolică şi protestantă}

Problema raporturilor dintre Biserica creştină şi necreştini s-a pus din primele veacuri, când Biserica a fost confruntată cu păgânismul, iar în Evul Mediu, cu musulmanii. Astăzi, datorită condițiilor de conviețuire cu totul schimbate, liderii religioşi şi credincioşii tuturor religiilor sunt obligați la o deschidere a unora față de ceilalţi, dându-şi mâna la împlinirea marilor provocări ale timpului nostru: pacea, înțelegerea şi colaborarea între popoarele lumii ${ }^{23}$.

Practicat uneori cu bune rezultate în mediile interconfesionale creştine, dialogul este cerut astăzi şi de unii dintre liderii marilor

${ }^{21}$ Hendrik Kreamer, Religion and the Christian Faith, London, Lutterworth Press, 1956, p. 147.

${ }^{22}$ Origen, Scrieri alese. Contra lui Celsus, PSB 9, Bucureşti, EIBMBOR, 1984, pp. 235-236.

${ }^{23}$ Drd. Ştefan Resceanu, Temeiuri pentru dialogul interreligios, în „Mitropolia Olteniei”, anul XXVI, nr. 1-2, 1974, p. 25. 
religii, îndeosebi de creştini, sperându-se ca pe această cale să se ajungă la o colaborare rodnică pentru binele omenirii, într-o vreme ca a noastră, în care pericolul unui război este iminent. În ultima perioadă, în sânul celor trei mari confesiuni creştine s-au schițat unele atitudini în problema dialogului interreligios, fără să se poată vorbi însă de o viziune comună în această privință nici măcar în interiorul fiecăreia dintre aceste confesiuni ${ }^{24}$.

Astăzi, Biserica Ortodoxă fiind un receptor sensibil al mesajelor vremurilor, dezvoltă dialoguri interreligioase monoteiste cu islamul şi cu iudaismul. Cele mai multe întâlniri ce au avut în centru dialogul intereligios, precum şi relaţiile dintre ortodocşi, evrei şi musulmani, s-au desfăşurat la Centrul Ortodox al Patriarhiei Ecumenice din Chambésy (Geneva), din iniţiativa Mitropolitului Damaskinos Papandreou al Elveției.

În ceea ce priveşte dialogul cu iudaismul, după o întâlnire pregătitoare la Geneva în 1976, până acum s-au realizat cinci întâlniri pe teme actuale.

Biserica Ortodoxă s-a întâlnit şi cu islamul şi a dialogat cu el sub diferite forme încă din primele decenii ale apariției acestuia. Arhiepiscopul Anastasios Yannoulatos distinge cinci faze ale dialogului dintre ortodocşi şi musulmani. Prima fază se întinde de la mijlocul sec. al VIII-lea până la mijlocul sec. al IX-lea d.Hr., atitudinea bizantină fiind mai curând ,persiflantă şi subestimativă" 25 . A doua fază este cuprinsă între mijlocul sec. al IX-lea şi mijlocul sec. al XIV-lea, când tactica adoptată de bizantini a fost una ofensivă, publicându-se multe opere referitoare la islam. A treia fază a confruntării cu islamul se desfăşoară între mijlocul sec. al XIV-lea şi mijlocul sec. al XV-lea şi se distinge prin „calm şi obiectivitate”26. Perioada dominatiiei otomane, care a urmat de la mijlocul sec. al XVlea până la mijlocul sec. al XIX-lea, a întrerupt dialogul care

24 Emilian Vasilescu, Cadrul şi perspectivele dialogului interreligios, în „Ortodoxia”, anul XXIII, nr. 1, 1971, p. 133.

${ }^{25} \uparrow$ Anastasios Yannoulatos, Ortodoxia şi problemele lumii contemporane, $\mathrm{p}$. 127.

${ }^{26}$ Ibidem, p. 129. 
începuse, Biserica Răsăritului având parte de experiențe dureroase. A cincea fază a dialogului dintre ortodocşi şi musulmani este epoca contemporană, în ultimele trei decenii dialogul promovându-se mai ales în cercurile universitare, de către reprezentanți ai ambelor religii ${ }^{27}$.

Interesul ortodocşilor pentru dialogul cu Islamul s-a manifestat şi mai puternic începând cu anul 1986, în urma colaborării Centrului Ortodox al Patriarhiei Ecumenice din Chambésy şi al Academiei Regale de Studii a Culturii Islamice (Al Albait Foundation, Amman, Iordania). Până acum s-au realizat zece întâlniri academice pe importante teme actuale ${ }^{28}$.

Deasemenea, Patriarhia Ecumenică a jucat un rol principal şi în organizarea unor Congrese şi Întâlniri Interreligioase Internaționale. Două asemenea congrese s-au desfăşurat la Constantinopol în 1994 şi 2005, acestea ducând la documentele cunoscute ca: „Declarațiile de la Bosfor", şi alte trei s-au desfăşurat la Bruxelles în 2001, Tesalonic în 2003 şi Amaroussion (Atena) în 2004, care au dus la Declarații asemănătoare $^{29}$. Rezultatul acestor Declarații este exprimat în poziția şi apelul din Declarația de la Amaroussion:

„Re pudiem orice formă de discriminare naționalistă, rasistă, religioasă, socială şi de alte forme, prin intermediul cărora se promovează intoleranța şi fanatismul morbid religios, precum şi încercarea de a găsi justificări pentru conflicte războinice şi terorismul organizat, în imensul detriment evident al coexistentei paşnice a tuturor oamenilor şi tuturor popoarelor. De aceea, lansăm un apel către conducătorii spirituali ai tuturor religiilor să întreprindă tot ce este necesar şi să coopereze pentru dezamorsarea acestor confuzii periculoase, pentru a putea astfel realiza propovăduirea cu adevărat

${ }^{27}$ Ibidem, p. 139.

${ }^{28}$ Î.P.S. dr. Damaskinos Papandreou, Dialogurile interreligioase şi întâlnirea celor trei religii monoteiste, în „Biserică, societate, lume”, Iaşi, Editura Trinitas, 1998, p. 286.

${ }^{29}$ George Martzelos, Orthodoxy and Interreligious Dialogue, A se vedea: http://www.apostoliki-

diakonia.gr/en main/catehism/theologia zoi/themata.asp?contents=selides kati xisis/contents_Texts.asp\&main $=$ SK_texts\&file $=5 . h$ tm $($ accesat în 27.04.2015). 
credibilă a voinței lui Dumnezeu ca pacea, dreptatea socială şi respectul pentru drepturile umane fundamentale să triumfe",30.

Dialogul interreligios al Ortodoxiei cu Iudaismul şi Islamul are ca rezultat adâncimea colaborării interreligioase prin care participanţii vor putea nu doar să depăşească experiența dureroasă şi tensiunile trecutului istoric, ci şi să abordeze împreună problemele sociale moderne care constituie o ameninţare la adresa omului şi a lumii.

„În urma dialogurilor cu Iudaismul şi cu Islamul, experiența Ortodoxiei a fost în permanentă dezvoltare şi în multe cazuri revelatoare pentru perspectivele pozitive ale unui dialog sincer şi ale unei intenții conştiente pentru colaborare interreligioasă atât în ce priveşte valorile spirituale în legătură cu Dumnezeu, cu omul şi cu lumea, cât şi cerințele omului postmodern privind protejarea păcii, a dreptăţii sociale precum şi a drepturilor omului" ${ }^{31}$.

În ceea ce priveşte dialogul interreligios în Biserica RomanoCatolică, prin documentul „Nostra Aetate: Declarație despre relaţiile Bisericii cu religiile necreştine" aprobat de Conciliul al II-lea de la Vatican în 28 octombrie 1965, reiese că Biserica Romano-Catolică îşi schimbă radical poziția față de oamenii altor religii şi mântuirea lor. De la o învățătură exclusivistă - „nu există mântuire în afara Bisericii" (adică Biserica Catolică) - ea a ajuns să recunoască faptul că Dumnezeu acționează în toate religiile şi să admită că El îşi exercită voinţa de mântuire şi în afară de Israel şi de creştinism (poziția inclusivistă). Chiar înainte de promulgarea acestui document, Biserica Romano-Catolică a acordat o atenție deosebită oamenilor de alte credințe religioase, înființând prin scrisoarea apostolică „Progrediente Concilio" a Papei Paul al VI-lea din 19 mai 1964 un „Secretariat pentru necreştini”, sub preşedinția cardinalului Paulo

30 Declarația de la Amaroussion, Interreligious Conference „Religion, Peace, and the Olympic Ideal" (Athens, Amaroussion, 10-11 august 2004), în Chryssavgis John (ed.), In the World, Yet Not Of the World. Social and Global Initiatives of Ecumenical Patriarch Bartholomew, New York, Fordham University Press, 2010, p. 312.

${ }^{31}$ Î.P.S. dr. Damaskinos Papandreou, art. cit., pp. 289-290. 
Marella. Menirea acestui secretariat este de a inspira, stimula şi coordona acțiunile Bisericii Romano-Catolice pe acest teren delicat al dialogului cu necreştinii ${ }^{32}$. Acest secretariat a fost redenumit „Consiliul Pontifical pentru Dialogul Interreligios” de Papa Ioan Paul al II-lea în 28 iunie 1988.

Biserica Romano-Catolică a continuat să dezvolte gândirea ei cu privire la raportarea față de oamenii altor credințe în documente cum ar fi Enciclica „Evangelii Nuntiandi” a Papei Paul al VI-lea din 8 decembrie 1975, care a subliniat o teologie de evanghelizare şi inculturație, precum şi Enciclica „Redemptor Hominis” a Papei Ioan Paul al II-lea din 3 martie 1979, care abordează problema evanghelizării şi mântuirii. Pentru că a fost nevoie de îndrumare cu atitudini schimbate, Secretariatul pentru necreştini a emis un document intitulat „Atitudinea Bisericii față de credincioşii altor religii: Reflecții şi orientări de Misiune şi Dialog" în 10 mai 1984. Pe aceeaşi linie practică, Vaticanul a produs în iunie 1985 un document de mare importanță religioasă şi politică intitulat „Note pentru o corectă prezentare a evreilor şi a iudaismului în predica şi cateheza Bisericii Catolice", care s-a dorit a fi un ajutor practic în teologia pastorală şi misionară. În 7 decembrie 1990 Papa Ioan Paul al II-lea a publicat pe aceeaşi temă Enciclica „Redemptoris Missio”, în care a ținut să sublinieze unicitatea lui Iisus Hristos ca Mântuitor, făă a relua ideea din Nostra Aetate care a afirmat mântuirea în alte religii. În 19 mai 1991 Consiliul Pontifical pentru Dialogul Interreligios (CPDI) a produs „Dialog şi Proclamare: reflecţie şi orientări privind dialogul interreligios, precum şi proclamarea Evangheliei lui Iisus Hristos", care a încercat să stabilească linia fină dintre dialog şi propovăduire $^{33}$.

În cadrul Bisericii Romano-Catolice un statut aparte i se acordă relației cu iudeii. Structural acest lucru se reflectă în faptul că

32 Diac. prof. Emilian Vasilescu, Cadrul şi perspectivele dialogului interreligios, p. 134.

${ }^{33}$ Gideon Goosen, Bringing Churches Together. A Popular Introduction to Ecumenism, revised and enlarged edition, Geneva, WCC Publications, 2001, p. 139. 
dialogul $\mathrm{cu}$ iudeii aparține unei Comisii separate pentru Relații Religioase cu iudeii şi nu CPDI, prin aceasta luându-se o poziție clară împotriva oricărei forme de antisemitism.

În ce priveşte atitudinea teologilor protestanți în problema raportării faţă de oamenii altor religii, se arată şi ei a fi foarte divizați, oscilând de la cele mai sincretiste la cele mai conservatoare şi fundamentaliste poziții. În vremurile anterioare, teologii protestanți liberali ca Frederick Schleiermacher, John Hick, Paul F. Kniter şi alții preconizau o largă deschidere faţă de religiile necreştine, cu riscul pericolului de sincretism religios. În schimb reprezentanţii „teologiei dialectice”34, Karl Barth, Hendrik Kraemer şi alţii au adoptat o atitudine care a fost caracterizată ca ,rigidă”, în sensul că aceşti teologi fac distincție clară între credința creştină, dar gratuit mântuitor al lui Dumnezeu, şi religiile necreştine, rezultat neputincios al eforturilor omeneşti de a atinge Absolutul. Dar s-a ivit în protestantism şi o a treia atitudine, aceea a curentului misionarecumenic, care oscilează între cei doi poli. Unii dintre adepții acestui curent, ca Paul Tillich, John Robinson, Joseph Sittler şi alţii, caută să stabilească legături între creştinism şi lumea necreştină prin teorii ca aceea a unei „Biserici latente” în sânul păgânismului (Paul Tillich) sau aceea a lui „Hristos cosmic” (Joseph Sittler). Alți reprezentanți ai acestui curent, ca Visser't Hooft, Lesslie Newbigin, Gerhard Rosenkranz, Stefan Neill, recunosc existența unei profunde pietăți în religiile necreştine şi cer dialogul şi colaborarea cu religiile necreștine, dar consideră că acestea trebuie limitate la domenii clar definite: de ordin cultural şi social, evitându-se discuţiile de ordin doctrinar ${ }^{35}$.

Marile confesiuni creştine consideră că există în religiile necreştine principii morale înalte, asemănătoare în unele privințe cu acelea ale creştinismului şi pe temeiul cărora se poate întreprinde o

\footnotetext{
${ }^{34}$ Anastasios Yannoulatos, Facing People of Other Faiths From an Orthodox Point of View, în „Greek Orthodox Theological Review”, vol. 38, nr. 1-4, 1993, p. 135.

${ }^{35}$ Diac. prof. univ. dr. Emilian Vasilescu, Istoria Religiilor, Ediţia a III-a, Bucureşti, Editura Didactică şi Pedagogică, 1998, pp. 409-410.
} 
colaborare fructuoasă spre binele omenirii. De aceea, ele privesc cu multă bunăvoință contactele cu reprezentanții religiilor necreştine şi fac tot ce este posibil în acest sens, manifestându-şi în acelaşi timp grija pentru păstrarea integrități mesajului creştin, care trebuie ferit de orice încercare de relativism şi sincretism religios ${ }^{36}$.

\section{Dialogul interreligios, un imperativ misionar al timpului nostru}

Situația istorică actuală, precum şi imperativele teologice ale credinței creştine, fac necesară preocuparea creştinilor pentru cultivarea şi continuarea dialogului interreligios. Prin urmare, una din sarcinile esențiale pe care le avem în acest sens, în calitate de creştini, este tocmai recunoaşterea acestui fapt, tratarea cu multă atenție a posibilităților şi problemelor legate de dialog, ca şi analizarea implicațiilor dialogului asupra vieții Bisericii într-o lume pluralistă ${ }^{37}$.

Astfel, există trei motive teologice solide pentru care dialogul este şi trebuie să fie un imperativ misionar al creştinilor. În primul rând, prin Iisus Hristos, Dumnezeu a intrat El Însuşi în relație cu oameni de toate credinţele şi din toate timpurile, oferind Evanghelia mântuirii. Din această perspectivă, Întruparea Mântuitorului reprezintă dialogul lui Dumnezeu cu lumea. În al doilea rând, încercarea de realizare a unei adevărate comunități, absolut indispensabilă din perspectiva Evangheliei lui Hristos, prin iertare, reconciliere şi o nouă creaţie, conduce în mod inevitabil la dialog. Pacea şi iubirea lui Hristos ne cer să regăsim comuniunea cu toți semenii noştri, indiferent de credința lor, pentru a putea deveni cu toții împreună cetățeni ai „,casei” lui Dumnezeu. Iar în al treilea rând, dar nu mai puțin semnificativ, există făgăduința lui Iisus Hristos în legătură cu faptul că Duhul Sfânt ne va descoperi adevărul: „Iar când

\footnotetext{
${ }^{36}$ Idem, Cadrul şi perspectivele dialogului interreligios, p. 139.

37 Stanley J. Samartha, Courage for Dialogue. Ecumenical issues in interreligious relationship, Geneva, WCC Publications, 1981, p. 1. A se vedea şi Nicolae Achimescu, Religii în dialog, p. 15.
} 
va veni Acela, Duhul Adevărului, vă va călăuzi la tot adevărul, căci nu va vorbi de la Sine, ci câte aude va vorbi şi cele viitoare vă va vesti" (In. 16, 3) ${ }^{38}$.

În societatea postmodernă actuală, procesul globalizării creează noi probleme urgente pentru întreaga omenire, şi de aceea este imperativ ca diversele comunități religioase să caute împreună răspunsuri eficace. Din această perspectivă, problemele cele mai practice pentru un dialog interreligios creator sunt noile provocări cu care umanitatea se confruntă într-o manieră intensivă datorită globalizării: probleme ecologice, sărăcia, reconcilierea, dreptatea, pacea etc. ${ }^{39}$.

In marea pluralitate religioasă de azi religiile trebuie luate foarte în serios. Credincioşii unei religii nu trebuie să ignore faptul că există şi credincioşi ai altor religii care trăiesc alături de ei în aceeaşi comunitate, oraş sau țară, şi care sunt partenerii şi interlocutorii lor în probleme de politică, cultură, învățământ, religie sau alte domenii. Acceptarea şi respectarea celor cu o religie diferită implică un efort de înţelegere a religiei acestora şi deschiderea necesară în vederea colaborării cu ei. Astfel, dialogul interreligios este postulat de pluralitatea religiilor în lume ${ }^{40}$.

Un element fundamental al timpului nostru îl constituie imperativul coexistenței paşnice într-o societate multiculturală. Trăim într-o lume însetată de contacte, întâlniri, înțelegere, armonie, unitate şi colaborare. Oamenii în general doresc să se întâlnească, să se asculte reciproc, să participe şi să vadă ce pot face împreună, în special pentru a construi o pace mai stabilă şi mai durabilă. Postomodernitatea, cu toate facilitățile ei de comunicare: e-mail, chat, telefon, fax, videointerfon, receptoare radio sau TV, staţii de emisie-recepție etc., acordă dialogului în sine, ca formă de

${ }_{39}^{38}$ Ibidem, pp. 12-14.

39 Anastasios Yannoulatos, Problems and Prospects of Inter-religious Dialogue. An Eastern Orthodox Perspective, în „The Ecumenical Review”, vol. 52, nr. 3, 2000, p. 355.

${ }^{40}$ Cardinal Francis Arinze, Dialogul interreligios, o necesitate a timpului nostru, în „Biserica Ortodoxă Română”, anul CXVI, nr. 7-12, 1998, p. 109. 
interacțiune umană, un rol poate mai accentuat ca niciodată în decursul istoriei, oferind oamenilor posibilitatea de a-şi comunica unii altora informaţii ${ }^{41}$. Deasemenea trebuie să fim conştienţi şi de pericolul reprezentat de înlocuirea dialogului viu dintre oameni cu dialogul mort, purtat prin intermediul tehnologiei actuale. In acest sens, „un rol decisiv este jucat de dialogul interreligios, al cărui țel îl reprezintă tocmai conştientizarea umanităţii asupra înţelegerii caracterului personal al relațiilor cu divinitatea şi între oameni deopotrivă" 42 . Oamenii îşi dau tot mai mult seama că au nevoie unii de alții şi că trebuie să construiască o comunitate mai armonioasă în toată lumea. În această lume, permanent în mişcare, religiile nu mai pot sta în izolare, izolaţionismul fiind condamnat din ce în ce mai mult. Adepții diferitelor religii sunt chemați să se întâlnească reciproc, să încerce să se înțeleagă mai bine şi să întrebe ce pot face împreună în calitate de credincioşi pentru a face din această lume un loc mai bun de trăit ${ }^{43}$.

Un alt imperativ misionar al timpului nostru este abordarea în comun a unor provocări şi probleme majore, cele mai importante fiind legate de dreptate şi pace, probleme care nu respectă frontierele religioase. In situațiile conflictuale, unii oameni sunt discriminaţi din cauza rasei, religiei, limbii, statutului social sau al sexului. Pe lângă acestea există situații de refuz al practicării solidarităţii între bogați şi săraci, la nivel național sau internațional, şi refuzul bogaților de a accepta faptul că posedarea bogăției, chiar justificată, atrage după sine responsabilități sociale avându-se în vedere destinația universală a bunurilor pământeşti. Se înregistrează apoi acte de discriminare împotriva femeilor şi a copiilor, mergând uneori până la condamnarea la a practica prostituţia în folosul stăpânilor. De asemenea, nu trebuie uitată nici plaga modernă cauzată de SIDA şi de abuzul de droguri care produc o suferință fizică şi morală, în unele

${ }^{41}$ David Pestroiu, Cadre actuale ale dialogului interreligios, în „Buletinul Centrului pentru dialog între ştiințe şi teologie”, anul VIII, nr. 1-2, 2011, p. 129.

42 Ibidem, p. 129.

${ }^{43}$ Cardinal Francis Arinze, art. cit., p. 109. 
cazuri reducând oamenii la nivelul sclaviei. Astfel, credincioşii diferitelor religii nu pot rămâne indiferenți în faţa unor asemenea provocări şi probleme, convinşi fiind că numai prin cooperarea interreligioasă vor găsi rezultatul durabil aşteptat ${ }^{44}$.

O realitate dură a lumii de azi pe care cooperarea interreligioasă este chemată să o rezolve o constituie stoparea violenței sub toate aspectele. De cele mai multe ori există tensiune care răbufneşte în violență deschisă, din motive etnice sau rasiale sau datorită unor răni istorice nevindecate. Uneori, există violență generată de frustrarea economică, şomaj, sărăcie şi de marginalizarea unor grupuri ale comunităţii. Alteori, violența izbucneşte datorită factorilor politici folosiţi de unele persoane interesate în scopuri personale. Un aparte tip de violență este cel provocat de sensibilităţile religioase interpretate greşit. Religia autentică nu constituie cauza violenței, dar dacă religia este folosită pentru motivarea angajării în acte violente, rezultatele pot fi dezastruoase, întrucât pentru motive religioase unii oameni nu ar ezita să-şi dea şi viața. Violența în lume a luat forma războaielor civile, atacurilor teroriste sau a actelor de fanatism religios cum ar fi epurarea etnică, toate acestea ducând la masacre de amploare şi chiar la genocid. Violenţa manifestată în numele religiei necesită o dezaprobare şi condamnare specială. Liderii spirituali au profunda datorie de a-şi conştientiza adepții împotriva folosirii violenței ca mijloc de propagare sau apărare a unei religii, dar şi de a face declaraţii personale atunci când se produc asemenea abuzuri. În faţa acestor realităţi, conducătorii religioşi sunt chemaţi să-şi unească eforturile în promovarea pocăinței, iertării, reconcilierii, dragostei şi unităţii ${ }^{45}$.

Pe lângă abordarea provocărilor stringente ale societății postmoderne, suntem conştienți că pentru cei care au răspunderea pastorală a comunității lor de credință, provocările sau încercările dialogului interreligios sunt în primul rând de ordin spiritual. Preafericitul Părinte Patriarh Daniel semnalează patru dintre

\footnotetext{
${ }^{44}$ Ibidem, pp. 109-110.

${ }^{45}$ Ibidem, p. 110.
} 
acestea $^{46}$. Prima provocare este cea a iubirii față de aproapele, prin care ne punem întrebarea dacă noi avem capacitatea de a-l primi pe străinul a cărui etnie şi religie sunt diferite de ale noastre. A doua provocare este cea pentru deşteptarea duhovnicească, când noi înconjurați fiind de oameni de alte credințe, putem învăța de la ei anumite valori pe care le-am uitat sau pe care le-am cultivat prea puțin, cum ar fi fervoarea rugăciunii, practica postului, bucuria ospitalității şi importanța centrală a familiei în viața omului, dimensiunea profundă a vieții comunitare, armonia relațiilor cu ceilalți. A treia provocare este cea a fidelității față de propria identitate religioasă, când ne întrebăm din nou dacă putem rămâne aceiaşi când totul este diferit în jurul nostru, dacă ne putem păstra identitatea religioasă fiind în minoritate, dacă putem rămâne creştini nepracticanți într-un context religios în care practicarea religiei este esențială pentru existența umană. A patra provocare şi ultima este cea a solidarității umane, prin rugăciune şi faptă cu minorităţile creştine aflate în dificultate sau chiar persecutate în diverse țări ale lumii ${ }^{47}$.

În acest context dinamic şi promiţător, religiile sunt chemate să aducă şi ele, de pe poziția lor specifică, o contribuție efectivă la realizarea, extinderea şi desăvârşirea acestui proces de cooperare a lumii de azi. Dar pentru a putea aduce această contribuție, trebuie mai întâi ca ele însele să acționeze în unitate. Or, în acest scop este absolut necesar dialogul interreligios, care este cea mai adecvată şi mai eficace metodă de apropiere între religii şi de punere de acord în ce priveşte modalităţile de îndeplinire a acestei contribuții. În contextul spiritului epocii noastre, deschis şi universal, religiile nu mai pot sta în izolare. Vremurile de azi cer tuturor religiilor să se apropie unele de altele, să se cunoască mai bine şi să-şi unească eforturile pentru a sprijini omenirea contemporană în aspirațiile ei de

46 Provocările dialogului interreligios, Conferința Preafericitului Părinte Daniel, Patriarhul Bisericii Ortodoxe Române, susținută la Catedrala „Notre Dame” din Strasbourg la 11 aprilie 2011, în „Ziarul Lumina”, Serie regională, anul II, nr. 89 (1893), 16 Aprilie 2011, p. 2.

${ }^{47}$ Ibidem, p. 3. 
înfrăţiire, de pace şi de fericire ${ }^{48}$.

\section{Concluzii}

Problema atitudinii şi a raportului creştinilor faţă de oamenii altor religii este stringentă pentru societatea postmodernă, ea constituind de altfel o problemă sensibilă pe tot parcursul istoriei creştine.

Din punct de vedere teologic atitudinea Bisericii Ortodoxe faţă de alte religii pe întreg parcursul existenței sale a fost una pozitivă, fără diluarea rolului lui Hristos în iconomia mântuirii, mai mult această atitudine fiind folosită ca o punte şi ca mijloc de a aduce împreună creştinii şi necreştinii.

În societatea actuală, procesul globalizării creează noi probleme urgente pentru întreaga omenire, şi de aceea este imperativ ca diversele comunităti religioase să caute împreună răspunsuri de încredere. Creştinii au în primul rând obligația morală de a se angaja într-un dialog cu oameni de alte convingeri religioase într-o atitudine de respect faţă de personalitatea celuilalt şi în spiritul smereniei lui Hristos.

Aşadar, dialogul interreligios este socotit un imperativ misionar al societăţii postmoderne, fiind singura alternativă de a depăşi conflictele etnice şi religioase, sociale şi economice, terorismele şi fundamentalismele care au măcinat umanitatea de la început şi care au fost izvor de suferinţă în toată istoria ei.

\section{Bibliografie:}

1. Biblia sau Sfânta Scriptură, tipărită sub îndrumarea şi cu purtarea de grijă a Prea Fericitului Părinte Teoctist, Patriarhul Bisericii Ortodoxe Române cu aprobarea Sfântului Sinod, Bucureşti, EIBMBOR, 1988.

2. Achimescu, Pr. Prof. Dr. Nicolae, Religii în dialog, Iaşi, Editura Trinitas, 2006.

48 Pr. prof. Corneliu Sîrbu, Pentru un dialog interreligios rodnic, în „Ortodoxia”, anul XXVII, nr. 2, 1975, p. 373. 
3. Arinze, Cardinal Francis, Dialogul interreligios, o necesitate a timpului nostru, în „Biserica Ortodoxă Română”, anul CXVI, nr. 7-12, 1998, pp. 108-111.

4. Ciobotea, Preafericitul Daniel, Provocările dialogului interreligios, Conferință susținută la Catedrala „Notre Dame” din Strasbourg la 11 aprilie 2011, în ,Ziarul Lumina”, Serie regională, anul II, nr. 89 (1893), 16 Aprilie 2011, pp. 2-3.

5. Chryssavgis, John (ed.), In The World, Yet Not Of the World. Social and Global Initiatives of Ecumenical Patriarch Bartholomew, New York, Fordham University Press, 2010.

6. Editorial, Necesitatea dialogului interreligios, în „Teologia”, anul VII, nr. 1, 2003, pp. 7-8.

7. Goosen, Gideon, Bringing Churches Together. A Popular Introduction to Ecumenism, revised and enlarged edition, Geneva, WCC Publications, 2001.

8. Jurcan, Pr. conf. univ. dr. Emil, Dialogul inter-religios în lumea contemporană, în „Orizonturi Teologice”, anul III, nr. 2, 2002, pp. 84-91.

9. Kreamer, Hendrik, Religion and the Christian Faith, London, Lutterworth Press, 1956.

10. Küng, Hans, Global Responsability: In Search of a New World Ethic, translation from German by John Bowden, SCM Press, 1991.

11. Maronese, Pr. Gianfranco, Dialogul dintre oameni, în „Pax et unitas”, nr. 3, 2004, pp. 3-4.

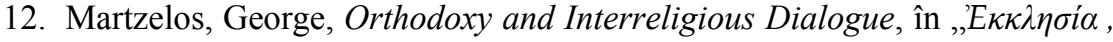

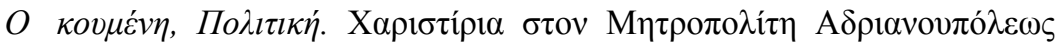
$\Delta \alpha \mu \alpha \sigma \kappa \eta$ ó”, $\quad$ Atena, 2007, pp. 437-444, http://users.auth.gr/ martzelo/index.files/arthra_n.htm (accesat în 29.04.2015).

13. Muck, Terry şi Adeney, Frances S., Christianity Encountering World Religions: The Practice of Mission in the Twenty-first Century, Grand Rapids, Baker Academic, 2009.

14. Oancea, Pr. prof. univ. dr. Dorin, Teologia Religiilor în Biserica Primară: Athenagoras, Sf. Justin Martirul, Origen, în Nicolae Moşoiu (coord.), „Relevanţa operei Părintelui Profesor Ion Bria pentru viaţa bisericească şi socială actuală. Direcții noi de cercetare în domeniul doctrinei, misiunii şi unității Bisericii”, Sibiu, Editura Universității „Lucian Blaga”, 2010, pp. 269-282.

15. Origen, Scrieri alese. Contra lui Celsus, PSB 9, Bucureşti, EIBMBOR, 1984.

16. Papandreou, Î.P.S. dr. Damaskinos, Dialogurile interreligioase şi 
întâlnirea celor trei religii monoteiste, în vol. „Biserică, societate, lume”, Iaşi, Editura Trinitas, 1999, pp. 269-302.

17. Pestroiu, David, Cadre actuale ale dialogului interreligios, în „Buletinul Centrului pentru dialog între ştiinţe şi teologie", anul VIII, nr. 1-2, 2011, pp. 129-137.

18. Resceanu, Drd. Ştefan, Temeiuri pentru dialogul interreligios, în „Mitropolia Olteniei”, anul XXVI, nr. 1-2, 1974, pp. 25-35.

19. Rus, Asist. Remus, Concepția despre om în marile religii, teză de doctorat, Bucureşti, 1978.

20. Samartha, Stanley J., Dialogue as a Continuing Christian Concern, în „The Ecumenical Review”, vol. 23, nr. 2, 1971, pp. 129-142.

21. Idem, Courage for Dialogue. Ecumenical Issues in Inter-religious Relationship, Geneva, WCC Publications, 1981.

22. Sfântul Iustin Martirul şi Filosoful, Apologeți de limbă greacăa, PSB 2, Bucureşti, EIBMBOR, 1980.

23. Sîrbu, Pr. prof. Corneliu, Pentru un dialog interreligios rodnic, în „Ortodoxia”, anul XXVII, nr. 2, 1975, pp. 373-384.

24. Vasilescu, Emilian, Cadrul şi perspectivele dialogului interreligios, în „Ortodoxia”, anul XXIII, nr. 1, 1971, pp. 133-138.

25. Idem, Istoria Religiilor, Ediția a III-a, Bucureşti, Editura Didactică şi Pedagogică, 1998.

26. Yannoulatos, Anastasios, Facing People of Other Faiths From an Orthodox Point of View, în „Greek Orthodox Theological Review”, vol. 38, nr. 1-4, 1993, pp. 131-152.

27. Idem, Problems and Prospects of Inter-religious Dialogue. An Eastern Orthodox Perspective, în „The Ecumenical Review”, Vol. 52, Nr. 3, 2000, pp. 351-357

28. Idem, Orthodox Relations with Other Religions, în „Sourozh”, nr. 85, 2001, pp. 6-21.

29. Idem, Ortodoxia şi problemele lumii contemporane, traducere de drd. Gabriel Mândrilă, pr. prof. dr. Constantin Coman, Bucureşti, Editura Bizantină, 2003.

30. Idem, Atitudinea Ortodoxiei față de alte religii, în „Cum să trăim Ortodoxia astăzi”, traducere din limba engleză de Doina Rogoti, București, Editura Sophia, 2010, pp. 224-244.

31. Idem, Misiune pe urmele lui Hristos. Studii teologice şi omilii, traducere de Ştefan L. Toma, Sibiu, Editura Andreiana, 2013. 